\title{
Impacts of Climate Change on Crop Production in Bangladesh: A Review
}

\author{
Md. Sazedur Rahman* \\ Statistics Discipline, Khulna University, Khulna-9208, Bangladesh \\ Md. Ashfikur Rahman \\ Development Studies Discipline, Khulna University, Khulna-9208, Bangladesh
}

\begin{abstract}
Climate change and its impact on human-environment are immeasurable because of its multidimensional effects. But the effect is not same for all countries, it depends on the countries geographical settings. Alongside location, education of the people, environmental awareness, somewhat might minimize the probability of loss in response to any kinds of disasters. Undertaken study was conducted based on an extensive published literatures (197-between 1995 and 2018) review with a view to consolidating the possible impacts of climate change on crop production in Bangladesh. It has found that already the impact has begun badly in Bangladesh. Temperature is gradually rising, frequency of floods, river bank erosion, storm surge, magnitude of cyclone, salinity intrusion, and the volatility of rainfall has increased comparing to past. All these led to the probability of decreasing the crop production. As climate change has become a great concern for countries food security, it is now the appropriate time to take and install proper rules and regulations through inflexible attitude. With the help of various international and national organizations government of Bangladesh inordinately trying to reduce the consequences of climate change. A comprehensive measurement must make sure to enhance the capability of encountering climate change, otherwise it will cost of enormous loss, especially on agriculture in Bangladesh.
\end{abstract}

Keywords: Climate change; Global warming, impacts of climate change; Crop production; Agriculture: sea level rising; Natural disaster; Coastal salinity.

\section{(9) (1) CC BY: Creative Commons Attribution License 4.0}

\section{Introduction}

Climate change is a significant global health threat of the $21^{\text {st }}$ century and it has become a great concern around the world [1-4]. The underdeveloped and developing countries are most vulnerable due to climate change for its direct impacts on socio-economic status [2, 5, 6]. Global warming has been the leading evidence for worldwide climate change $[4,7]$. The temperature of the earth is increasing significantly and could be increased by $2^{0}$ to $6^{0}$ Celsius by the end of $21^{\text {st }}$ compared to the end of the 20th century [8]. Bangladesh is flat, low-lying riparian, flown over by many numerous rivers, $80 \%$ land are floodplains and densely populated nation of over 160 million people in a land of $147,570 \mathrm{~km}^{2}[1,2,5,7]$. The Bay of Bengal is in the south of the country and the country has a 711

$\mathrm{km}$ long coastline with a vast flow of the Ganges-Brahmaputra-Meghna (GBM) Himalayan River system [1, 5]. The coastal region covers $47,203 \mathrm{~km}^{2}$ of total land of Bangladesh and the population of coastal area is 40 million (about $28 \%$ of total population of the country) which is predicted to be 57.9 million in 2050 [9]. Bangladesh was ranked $5^{\text {th }}$ among 170 countries in the Global Climate Risk Index in the period 1994-2013 [10].

In recent years, Bangladesh achieved enormous success in economic growth and poverty reduction, where, poverty has been reduced almost 26\% from 1991 to 2010 [11-13]. Agriculture has been playing the dominant sector for economic growth for a long [14, 15]. Alongside providing raw materials for industries, agriculture plays a significant role in ensuring country's food security; rural poverty reduction, employment generation, and importing foreign currency [16]. A very large portion of Bangladeshi people are directly or indirectly depend on agricultural activities or they are benefited by agriculture. This sector shared almost $14.22 \%$ of the total national GDP in 2016 [17], although it is in gradual decreasing rate at 5\% from 2010 [18]. Agriculture can be divided in different subsectors including crop, livestock, agro-forestry, fisheries. In Bangladesh, crop is the main sub-sector of agriculture and rice dominates major share (71\%) of crop production [19]. Rice (Oriza sativa) is the main food crop and jute (Corchorus capsularies) is the principal cash crop in the country. Aus, aman and boro are the three main varieties of rice are being produced here.

Climate variables including temperature, rainfall, length of day, humidity have significant negative impact on agriculture $[18,20]$. So, agriculture is highly vulnerable sector to climate change, for example, in Africa, due to climate change nearly two-thirds of arable land would be lost by 2025 and by 2080 agricultural productivity will be reduced from $21 \%$ to $9 \%[20,21]$. As a result, availability of food to feed the predicted population of nine billion by 2050 will be threaten [22]. Global hunger still a serious problem, especially for South-Asia and Sub-Saharan Africa, and the population of these regions are going to experience severe hunger by 2080 due to climate change in upcoming time [22-24]. In addition, food and oil prices might rise dramatically which can force 130 to 155 million more people in the world into extreme poverty; malnutrition will appear as a double burden in South Asia including Bangladesh [22]. 
The issue of climate change and its adverse impact on food production has been recognized in Bangladesh extensively. Because, in the country, food production often face tremendous difficulties due to climate change [14, 25-28]. Seasonal characteristics, $\mathrm{CO}_{2}$, rainfall, light intensity, temperature, soil and water salinity are strongly influencing to the agricultural activities in Bangladesh [27, 29]. Mondal [30], found that approximately 80000 hector of arable land be going out of production in every year and country's crop production is frequently affected by flood, drought and salinity. As a result, crop productivity as well as food security would be seriously threatened. The main objective of the study is to review climate change in Bangladesh and its impacts on crop production in Bangladesh.

\section{Methods}

An iterative search process was used for further consideration and review. A broad literature search was obtained from Google Scholar (https://scholar.google.com/). Between September 10 and October 25, 2018, we searched Google Scholar using keywords 'impacts' 'climate change', 'global warming', 'food production', 'crop production', 'food security', 'Bangladesh' 'sea level rising', 'natural disaster' 'coastal salinity', 'agriculture' and 'fisheries'. We also searched Springer Online Journal (https://link.springer.com/) and Elsevier ScienceDirect (https://www.sciencedirect.com/) with similar keywords. The attention was given on articles published by peer reviewed journal between 1995 and 2018. In this entire paper we attempted to explore the answer of the question 'What are the effects of climate change on crop production in Bangladesh?'. Initially, approximately 1214 publications were identified, but after review of the abstracts led to an elimination of 168 articles for further review as a lack of relevance. Also, more 71 articles were excluded for not providing relevant information. Finally, 97 articles, books and reports were included in this review study (Figure 1). From the depth review of these articles, the following results were found.

\section{Results}

\subsection{Climate Change in Bangladesh}

Global warming refers to the continuous increasing of the earth's climate system, is a result of greenhouse gas emission. From the beginning of the industrial revolution, carbon dioxide $\left(\mathrm{CO}_{2}\right)$ has increased by over $30 \%$ and is now at a higher concentration in the atmosphere as a result of increasing uses of burning of fossil fuels, coal, oil and gas [31]. The greenhouse gases (carbon dioxide, nitrous oxide, methane, sulfur dioxide etc.) leads to a warming of the earth that is known as 'Global Warming'. Extreme weather events, rising sea level, melting of glaciers and seaice, damage coral, changes in wildlife distribution and health, abundance of disease vectors, agricultural and public health damage are very common result of global warming [1-10,13]. Besides adverse impact on agriculture, rising $\mathrm{CO}_{2}$ could cut down the protein content of cereal, for instances, the protein contents of rice, wheat, barley and potato would be decreased by $7.6 \%, 7.8 \% .14 .1 \%$ and $6.4 \%$, respectively. This falling protein would increase the number of malnourished individual throughout the world including Bangladesh. And now human existence and natural resources are at great risk for sustaining in future.

Figure-1. Diagram of review methods

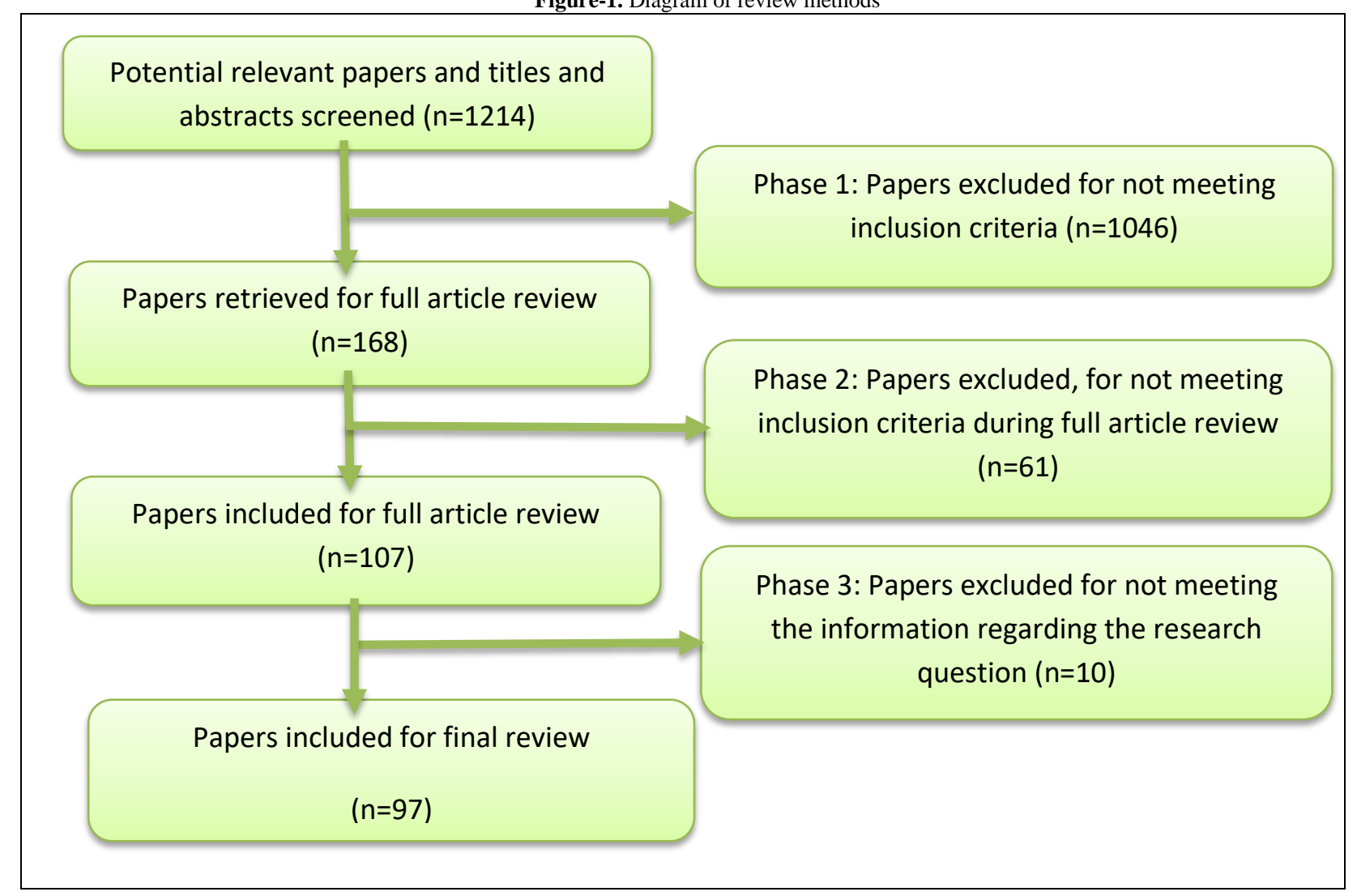


Bangladesh has already begun to experience the adverse effects of global warming by extreme river floods, tropical cyclones, rising sea level, coastal erosion, droughts and very high temperatures [1, 2], [5], [9, 10], [14], [17], $[18,19],[25,27-30,32]$. Bangladesh has ranked $5^{\text {th }}$ according to Global Climate Risk Index [10]. During the period 1994-2013, Bangladesh faced 228 extreme events like cyclone Sidr and Aila with gross loses of 3128.80 million dollar [10]. The onset of the monsoon in Bangladesh is predicted to delay in near future which has serious consequences on the environment, economic, health and food security [33]. In 2007, about 3500 individuals were dead, almost 2 million people were displaced, and almost million tons of food was damaged by the devastating cyclone Sidr [34].

\subsection{Sea Level Rising}

The result of sea level rising (SLR) due to global warming has made the global attention extraordinarily. National Aeronautics and Space Administration (NASA) estimated sea level rising as a rate of $3.2 \mathrm{~mm}$ per year between 1993 and 2015 due to melting polar ice caps and seawater expansion [35]. During the 20 century, sea levels rose by an average of 10 to $20 \mathrm{~cm}$ around the world, which is ten times higher than the average rate of over the last 3000 years and if it happens continuously, thousands of square miles including eastern U.S. and Bangladesh will be lost [36]. It is projected that the world temperature could rise by $1.1^{0} \mathrm{C}$ to $3.5^{\circ} \mathrm{C}$ with sea level rise $28 \mathrm{~cm}$ to $98 \mathrm{~cm}$ at 2100 compared to the $20^{\text {th }}$ century [8].

Bangladesh with the Bay of Bengal on the South is highly vulnerable to sea level rising as low-lying country [37-41]. There is evidence that that the sea level rise at Hiron Point in the Sundarbans was $4.00 \mathrm{~mm}$ per year and it was $7.8 \mathrm{~mm} /$ year in Cox's Bazar station [42, 43]. A similar result found by Rahman [44] and Sarwar [45] transpired that the sea level rise occurred at Hiron Point in the Sundarbans was $3.38 \mathrm{~mm}$ per year, along the central coast as $5.73 \mathrm{~mm}$ per year. The authors of the two studies considered that this sea level rise in Sundarbans as low vulnerable as it showed similar trend of global SLR. In these study, Patuakhali, Bhola, Monpura and Hatiya Island was found as mostly vulnerable to SLR whereas Noakhali Feni Coastal zone was found as moderately vulnerable in Bangladesh. Ahmed, et al. [37] predicted that in Bangladesh sea level will rise by $30 \mathrm{~cm}$ and temperature will rise by $0.7^{0} \mathrm{C}$ and $1.3^{0} \mathrm{C}$ in monsoon and in winter respectively in 2030 compared to base year 1990 whereas in 2050 the sea level will rise by $50 \mathrm{~cm}$ and temperature by $1.1^{0} \mathrm{C}$ in monsoon and $1.8^{0} \mathrm{C}$ in winter (Table 1 ).

Table-1. Prediction of SLR and temperature in 2030 and 2050 in Bangladesh

\begin{tabular}{l|l|l}
\hline \multirow{2}{*}{ Year } & \multicolumn{3}{|l}{ Climate Change Scenarios } \\
\cline { 2 - 3 } & Sea Level Rise $(\mathbf{c m})$ & Temperature Increase $\left({ }^{\mathbf{0}} \mathbf{C}\right)$ \\
\hline 2030 & 30 & +0.7 in monsoon; +1.3 in winter \\
\hline 2050 & 50 & +1.1 in monsoon; +1.8 in winter \\
\hline
\end{tabular}

Source: [37]. On base year (1990): average winter temp: 19.90C and average monsoon temp: $28.7^{0} \mathrm{C}^{40}$

\subsection{Impacts of Sea Level Rise on Crop Production}

In 2000, World Bank predicted that in Bangladesh sea level would rise at $10 \mathrm{~cm}, 25 \mathrm{~cm}$ and $1 \mathrm{~m}$ in 2020,2050 and 2100 respectively [15]. SLR poses an adverse impact in environment. With the increase of SLR, occurrence of inundation, salinity intrusion, storm surge and flooding also increase [46]. Table 2 shows the negative impacts of SLR in 2020, 2050 and 2100. For example, with the increasing SLR, 4\% of the countries land $\left(6300 \mathrm{~km}^{2}\right) \mathrm{would}^{2}$ inundate by 2050 and $17.5 \%$ of the total land $\left(25000 \mathrm{~km}^{2}\right)$ would be inundated by the end of the century. Huq, et al. [17] and Sarwar and Khan [41] found almost similar impacts of $1 \mathrm{~m}$ SLR. For instance, Huq et al. found in their study that if sea level will rise by $1 \mathrm{~m}$, then in Bangladesh, almost $25000 \mathrm{~km}^{2}$ of land (>17.5\% of total land) could be inundation, more than 1.2 million ha of arable land could be lost, 13 million population could be displaced and the world largest mangrove forest, Sundarbans would be totally distracted [17]. A one-meter SLR will cause salinity intrusion, river bank erosion, crop failure, frequent floods and storm surges, increase in cyclone intensity, loss of biodiversity, fisheries destruction, lack of fresh water which will affect all the ecosystem of the country [14, 38, 41]. The arable land will be decreased and wholeheartedly which may affect the entire countries food supplying system beside the water resources will be drastically reduced; which may break down the whole environmental system [18, 29].

The two major effect of sea level rising in Bangladesh assumed by Faisal and Parveen [27]. The first is saltwater intrusion which underlies the delta's fresh ground water and the second is increasing the number of inundation. Both the problems have adverse negative impact on crop production [29]. Of 100\% land, 30\% of the land of Bangladesh is situated in this coastal region; about 1 million hector of the coastal land is polluted by salt. 
Table- 2. Possible impacts of different forms climate change in Bangladesh

\begin{tabular}{|c|c|c|c|}
\hline Year & 2020 & 2050 & 2100 \\
\hline Sea level rise & $10 \mathrm{~cm}$ & $25 \mathrm{~cm}$ & $1 \mathrm{~m}$ \\
\hline Land below SLR & $\begin{array}{l}2 \% \text { of the total } \\
\text { land }=2500 \mathrm{~km}^{2} \text {. }\end{array}$ & $4 \%$ of land $=6300 \mathrm{~km}^{2}$. & $\begin{array}{l}17.5 \% \text { of land }=25000 \mathrm{~km}^{2} . \\
\text { Patuakhali, Khulna and } \\
\text { Barisal regions most affected. }\end{array}$ \\
\hline Storm surge & - & $\begin{array}{l}\text { A cycle like } 1991 \text { happens } \\
\text { again with a } 10 \% \text { increase in } \\
\text { intensity, storm surge goes } \\
\text { from } 7.1 \text { to } 8.6 \mathrm{~m} \text { with } 0.3 \mathrm{~m} \\
\text { SLR }\end{array}$ & $\begin{array}{l}\text { Storm surge goes from } 7.4 \text { to } \\
9.1 \mathrm{~m} \text { with } 1 \mathrm{~m} \mathrm{SLR}\end{array}$ \\
\hline Salinity & Increase & Increase & Increase \\
\hline Flooding & $\begin{array}{l}20 \% \text { increase in } \\
\text { areas subject to } \\
\text { flooding. }\end{array}$ & $\begin{array}{l}\text { Increase flooding in Meghna } \\
\text { and Ganges floodplain. }\end{array}$ & $\begin{array}{l}\text { Both inundation area and } \\
\text { flood intensity will increase } \\
\text { tremendously. Devastating } \\
\text { flood may cause crop failure } \\
\text { for any year. }\end{array}$ \\
\hline
\end{tabular}

The volume of salty land has increased about 26\% between 1979 and 2014 [28], and it has been anticipated that the soil salinity will increase $39 \%$ by 2050 [29]. As a result, the food production will be threatened and there are many evidence that salinity is already cutting into the crop yields in Bangladesh. A study of Shatkhira district, pointed out that salinity is the principal cause of decreasing crop production [47]. And every year a large volume of land is becoming infertile and are also not being utilized for further crop production. Habibullah, et al. [48] estimated that because of salinity, 272000 ton rice would be lost in 2030 which is about 1.4 times higher compared to 1990 (196000 ton) (Table 3) although this impact is relatively lessen than impacts of $\mathrm{CO}_{2}$ fertilization, temperature change, and inundation [27].

Table-3. Prediction of possible loss of rice production due to salinity

\begin{tabular}{l|l|l|l}
\hline Year & \multicolumn{3}{|c}{ Loss of rice production due to salinity (in '000 ton) } \\
\hline & Aus & Aman & Total \\
\hline $\mathbf{1 9 9 0}$ (Base Year) & 65.60 & 130.80 & 196.40 \\
\hline $\mathbf{2 0 3 0}$ & 75.80 & 196.20 & 272.00 \\
\hline \multicolumn{4}{l}{} \\
\hline
\end{tabular}

In addition, because of salinization, canals and ponds of the coastal regions will suffer environmental degradation including lessening of grazing field and loss of livestock, loss of bio-diversity (for example, decrease in tree species and freshwater fishes), degradation of land productivity, displacement of family and internal migration [29, 49-52]. This could have dramatic consequences for Bangladeshi economy with a GDP decrease in the result of $28 \%$ to $57 \%$. $^{2}$

\subsection{Impacts of Floods and Cyclones on Crop Production}

Rising temperature will lead to stronger and frequent cyclones and storms in the Bay of Bengal [14]. Almost every year, Bangladesh, particularly the coastal regions face natural calamities like floods, cyclones, storms, and tidal bores and nearly $80 \%$ area is prone to flooding [46]. Normally, in every year, 30-70\% the country is flooded $[17,53]$. Warmer climate will increase this flood risks [54]. Mirza [55] demonstrated four distinct types of floods occurs in Bangladesh: a) flash floods, resulting from heavy rainfall which occur on the eastern and northern rivers, b) riverine floods due to vast flow of the Ganges-Brahmaputra-Meghna (GBM), c) rain floods, because of high intensity of local monsoon rainfall; and d) storm surge floods due to tropical storms and cyclones. However, once every four to five years, severe and devastating floods bring substantial damage to agriculture, livestock, human health, infrastructure and housing [56]. Over the last few decades, floods disasters have been significantly increased worldwide [57], and Bangladesh is not an exception. From 1954 to 2010, Bangladesh experienced twenty-one above normal floods, four exceptional floods, and two catastrophic floods [58-60].

Agriculture is the most vulnerable and affected sector in Bangladesh in response to flood [33, 53]. In a study of Ahmed [53] informed that production of agricultural products 45\% reduced for 1988 devastating flood, again in 1998 more than 2 million hectares of crop land was swamped by flood water. A study by Dasgupta and Susmita [26] estimated that flood in 2007 submerged approximately $42 \%$ of the country's land, drowned 2.1 million hectares of arable land and affected 14 million people.

Coastal area of Bangladesh is highly susceptible due to cyclonic storms and flood for its natural settings alongside tropical cyclone made this area of highly vulnerable to be affected by natural disasters [37]. But to some extent flood has be considered in Bangladesh for the betterment of the agriculture, because floods bring much sediments and make the land fertile, but the intensification of gigantic floods and rapidly growing global warming making this situation more volatile and problematic [61].

Almost 2.6 million ha crops are being affected and damaged every year caused by severe floods in Bangladesh. A recent study by Mohammed and Khaled [62] found that the magnitude of floods may be much more severe in the upcoming future in Bangladesh. They have projected that if the temperature will increase by $2^{\circ} \mathrm{C}$, within a hundred year time period the flood flows will increase by $29 \%, 24 \%$ and $38 \%$ respectively in Ganges, Brahmaputra and 
Meghna rivers [62]. In 2004, the devastating flood inundated 38\% of the total countries land and caused heavy loss of crops and human life [30, 63]. Rana and Islam [64] conducted a study on three districts of Bangladesh; Kurigram, Faridpur and Kushtia had found that the 1998 flood destroyed 418,044 metric tons crops in Faridpur, 252,660 in Kurigram, and about 127,527 metric tons in Kushtia. The monetary value of the total crop damage was equivalent to USD 91.89 million.

A study of Parvin, et al. [65] in Rajbari district of Bangladesh had found that during the flood of 2004, 89\% of the Aus, 93\% of Aman rice area and $73 \%$ of the jute area were damaged. In addition, they found that $23.3 \%$ of agricultural labor loss their work and $46.5 \%$ had obliged to shift their profession from agriculture to other. A similar study conducted by Islam [66], described that during monsoon flood season (August-October) 79\% households moved from agriculture to non-farm activities whereas $20 \%$ bound to be live without work. Gray and Mueller [67] found that of the total household expenditure, $20 \%$ damaged because of flooding and $12 \%$ for crop failure in every event.

Rahman and Salehin [68] mentioned that the frequency and extent of floods have been soared in Bangladesh due to its natural circumstances. For instance, Harun-ur-Rashid and Islam [69] found that in 2012 flash flood damaged 80,000 acres shelter and crop land in two district (Chittagong and Cox's Bazar).Floods in Bangladesh generally take place during July to September when paddy (Aus and Aman), summer vegetables and several cash crops including jute and sugarcane are in the land [70]. Food security is one of the main target of the Bangladeshi government and the authority also imposes subsidies in food and agriculture to improve the food production [71]. Many flood control projects have been introduced in the country over 50 years, but the projects have not been able to reduce the risk of larger floods [72].

Floods bring multidimensional negative impacts to agriculture and improper management creates heavy loss of lives and agricultural products. Generally floods take place in Bangladesh July to September when (Aus, Aman), summer vegetables and several cash crops including jute and sugarcane are in the final stage of extracting from the cornfield [68]. Although, over the last 50 years many flood control projects or damps have established in different areas of Bangladesh, but the projects have not been able to reduce the risk of floods [69]. For example, almost 113465 metric ton, 125250 metric ton and 102254 metric Aman rice had destroyed due to floods in 2007-08, 201415 and 2015-16 respectively (table 4). The losses of crop production due to recent floods in Bangladesh has placed in table 4.

Table- 4. The losses of crop production due to recent floods in Bangladesh

\begin{tabular}{l|l|l|l|l|l|l|l}
\hline Crop's name & \multicolumn{6}{|l}{ Loss in production (M.ton) due to floods from 2007 to 2015 } \\
\hline & $\mathbf{2 0 0 7 - 0 8}$ & $\mathbf{2 0 0 8 - 0 9}$ & $\mathbf{2 0 1 0 - 1 1}$ & $\mathbf{2 0 0 9 - 1 0}$ & $\mathbf{2 0 1 1 - 1 2}$ & $\mathbf{2 0 1 4 - 1 5}$ & $\mathbf{2 0 1 5 - 1 6}$ \\
\hline Aus & 94164 & 990 & - & - & 7519 & 7077 & 17395 \\
\hline Aman & 230681 & 113465 & 12580 & - & 70014 & 125250 & 102254 \\
\hline Boro & - & - & - & 369591 & - & - & 97592 \\
\hline Jute & 46145 & - & - & - & - & - & - \\
\hline Sugarcane & 116387 & - & - & - & - & - & - \\
\hline Vegetables & 99614 & 670 & - & - & 5242 & 79 & - \\
\hline Banana & 7014 & - & - & - & - & - & - \\
\hline Pineapple & 2815 & - & - & - & - & - & - \\
\hline Papaya & 2386 & 30034 & - & - & - & - & - \\
\hline Maize & 1743 & 745 & - & - & - & - & - \\
\hline Ginger & 1084 & - & - & - & - & - & - \\
\hline Chilies & 2204 & 622 & - & - & 2542 & - & - \\
\hline Sources- & &
\end{tabular}

Sources- [73, 74], M.ton, Metric ton.

Natural disaster is a common scenario in Bangladesh. At least 174 natural disasters already affected Bangladesh from 1974 to 2004 [75]. Cyclone killed 500,000 in 1970, 140,000 in 1991 and 3406 in 2007 [76]. Cyclone in 1991 damaged approximately $60 \%$ of cattle, $80 \%$ of poultry stocks, and 280,000 acres of standing crops [77]. Kausher, et al. [77] estimated the aggregated losses for the cyclone in 1991 was US\$ 4 billion. With the maximum speed of 225 $\mathrm{kmh}^{-1}$, the cyclone of 1991 hit Bangladesh and killed about 138000 people. Ali [78] found by developing a model that if the temperature will rise by $2{ }^{0} \mathrm{C}$ and $4{ }^{0} \mathrm{C}$ then the wind speed of the cyclone will $248 \mathrm{Kmh}^{-1}$ and $275 \mathrm{Kmh}^{-1}$. Any increase of storm surge water may easily flooded country's low and flat terrain. These extreme events will bring serious damage to country's economy, agriculture, food security, infrastructure and ultimately human existence. However, cyclone Sidr in 2007 damaged 16,10,000 hector crop land and killed 468000 livestock's with huge economic loss estimated as US\$ 3 billion [52]. Khan, et al. [79] revealed that during 1999-2012, agricultural land and vegetation were declined by $48 \%$ and $3 \%$, respectively.

\subsection{Drought}

For the livelihoods, most of the people in Bangladesh depend on its natural resources. Global warming has contributed more frequent, severe and vast extent of the recent droughts [80-82]. It threats to food security in many regions worldwide including Bangladesh [80, 83]. For instance, the northwestern region of the country, experienced one of the most severe droughts of the century, which started in October 1994 and was broken in July 1995 with the onset of monsoon rain, was the major factor for crop damage between 1994 and 1995 in Bangladesh, led to a shorten of rice production of 3.5 million tons [80]. Rahman, et al. [83] showed that drought caused 25 to $30 \%$ of crop reduction in the northwest part in Bangladesh. About 17\% of the Aman crops are lost due drought in a year [84]. 
In South Asia, the precipitation in the dry season has decreased and in the monsoon season has increased which will cause more extreme droughts and floods in this region [80]. In recent years, Bangladesh has already faced an increased frequency of droughts [82]. Crop production, water management and power generation mostly depend on precipitation [80]. With an increase of demand for water, water stress and reduction of soil moisture responsible for decreasing crop yields. In pre-monsoon (March-May) and post-monsoon (October-November) seasons, droughts mostly appear in Bangladesh [85]. Also, droughts appear in monsoon (May-October) and winter season (DecemberFebruary).

Drought adversely affects all three rice varieties (aman, aus and boro), wheat, sugarcane, and potatoes [86, 87]. It also have direct impact on jute, potatoes, oilseeds, minor grains, winter vegetables, and sugarcane. Although most of the region in Bangladesh are affected by draught, it is more frequent in the northwest part of the country [85-94]. Alamgir, et al. [95] depicted that Pre-monsoon droughts are more prevalent in the northwest, monsoon droughts are more frequent in west and northwest and the winter droughts mainly affect in the west. However, Shahid and Hazarika [94] revealed that almost $42 \%$ of northwestern Bangladesh suffer from groundwater scarcity in summer season due to irrigation and drought. Longer and more intense droughts affected its agriculture severely and destroys crops as well as food production in every year.

\section{Conclusions}

Despite having very low contribution to generate total global greenhouse gas emissions Bangladesh is now considered the most vulnerable country in the globe due to global warming. The geographical circumstances make this country more susceptible to the natural effect i.e. (global warming, cyclones, floods, storm surge etc.). Further, high congested population and low elevation, flat deltaic topography has exaggerated the probability of more loss in response to any kinds of disasters. This review paper attempted to consolidate various study findings and projection which have made different times for Bangladesh in result of disaster or global temperature rising on crop production. The extensive literature review summarizes inhere that Bangladesh is at great danger on crop production due to climate change and climate change is slowing its crop yields. A large portion of the country are highly susceptible to go under water in response to sea level rise which will lead to the boundless damage to agriculture, aqua culture, livestock raring and the whole effect will be lessened the total food production overwhelmingly. Consequently it may break down the total human-environment. Although, Bangladeshi government in collaboration with different organizations and countries attempting to reduce the impacts of global warming alongside government is consistently determine to find out the best adaptive strategy to empower the vulnerable people. As the people of Bangladeshi are not so much aware of following environmental-rules and regulations so awareness building program must make sure through newspaper, radio or TV-media and inserting climate issues in schoolbook at primary level. It is now the appropriate time to take and install proper rules and regulations through inflexible attitude.

Conflict of interest: Nil

\section{References}

[1] Agrawala, S., Ota, T., Ahmed, A. U., Smith, J., and Van, A. M., 2003. Development and climate change in Bangladesh, Focus on coastal flooding and the Sundarbans. Paris: OECD.

[2] Mahmood, S. A., 2014. "Impact of climate change in Bangladesh, Role of two governments." Journal of Ecology and The Natural Environment, vol. 6, pp. 119-125.

[3] McMichael, A. J., Woodruff, R. E., and Hales, S., 2006. "Climate change and human health, Present and future risks." The Lancet, vol. 367, pp. 859-869.

[4] Walther, G. R., Post, E., Convey, P., Menzel, A., Parmesan, C., Beebee, T. J., Fromentin, J. M., HoeghGuldberg, O., and Bairlein, F., 2002. "Ecological responses to recent climate change." Nature, vol. 416, p. 389.

[5] Elahi, K. M., 2016. Climate change and health impacts in Bangladesh. In climate change and human health scenario in south and Southeast Asia. Springer, Cham.

[6] Mendelsohn, R., Dinar, A., and Williams, L., 2006. "The distributional impact of climate change on rich and poor countries." Environment and Development Economics, vol. 11, pp. 159-178.

[7] Pender, J. S., 2008. What is climate change? and how it will effect Bangladesh. Briefing paper, final draft. Dhaka, Bangladesh: Church of Bangladesh Social Development Programme.

[8] Field, C. B., 2014. Climate change 2014-Impacts, Adaptation and vulnerability, Regional aspects. Cambridge University Press.

[9] Minar, M. H., Hossain, M. B., and Shamsuddin, M. D., 2013. "Climate change and coastal zone of Bangladesh, Vulnerability, Resilience and adaptability." Middle-East Journal of Scientific Research, vol. 13, pp. 114-120.

[10] Kreft, S., Eckstein, D., Junghans, L., Kerestan, C., and Hagen, U., 2013. "Global climate risk index 2014. Who suffers most from extreme weather events." vol. 1Á, p. 31.

[11] Bangladesh Ministry of Finance's Bureau of Statistics, 2003. Report of the Household Income and Expenditure Survey 2000. Dhaka, Bangladesh: Government of Bangladesh.

[12] Bangladesh Ministry of Finance's Bureau of Statistics, 2011. Report of the Household Income and Expenditure Survey 2010. Dhaka, Bangladesh: Government of Bangladesh.

[13] Yosef, S., Jones, A. D., Chakraborty, B., and Gillespie, S., 2015. "Agriculture and nutrition in Bangladesh, Mapping evidence to pathways." Food and Nutrition Bulletin, vol. 36, pp. 387-404. 
[14] Davis, K. F., Bhattachan, A., D’Odorico, P., and Suweis, S., 2018. "A universal model for predicting human migration under climate change: examining future sea level rise in Bangladesh." Environmental Research Letters, vol. 13, p. 064030.

[15] World Bank, 2000. "Bangladesh, Climate change \& sustainable development. Report No. 21104 BD, Dhaka."

[16] Mozumdar, L., 2012. "Agricultural productivity and food security in the developing world." Bangladesh Journal of Agricultural Economics, vol. 35, pp. 53-69.

[17] Huq, S., Ali, S. I., and Rahman, A. A., 1995. "Sea-level rise and Bangladesh, A preliminary analysis." Journal of Coastal Research, pp. 44-53.

[18] Brammer, H., 2014. "Bangladesh's dynamic coastal regions and sea-level rise." Climate Risk Management, vol. 1, pp. 51-62.

[19] Shahid, S., 2011. "Impact of climate change on irrigation water demand of dry season Boro rice in northwest Bangladesh." Climatic Change, vol. 105, pp. 433-453.

[20] Masipa, T. S., 2017. "The impact of climate change on food security in South Africa, Current realities and challenges ahead." Jàmbá, Journal of Disaster Risk Studies, vol. 9, pp. 1-7.

[21] Liliana, H., 2005. "The food gaps, The impacts of climate change on food production, A 2020 perspective."

[22] Black and Robert, E., 2013. "Maternal and child undernutrition and overweight in low-income and middleincome countries." The lancet, vol. 382, pp. 427-451.

[23] Kotir, J. H., 2011. "Climate change and variability in Sub-Saharan Africa, A review of current and future trends and impacts on agriculture and food security." Environment, Development and Sustainability, vol. 13, pp. 587-605.

[24] Schmidhuber, J. and Tubiello, F. N., 2007. "Global food security under climate change." Proceedings of the National Academy of Sciences, vol. 104, pp. 19703-19708.

[25] Basak, J. K., Ali, M. A., Islam, M. N., and Rashid, M. A., 2010. "Assessment of the effect of climate change on boro rice production in Bangladesh using DSSAT model." J. Civ. Eng., vol. 38, pp. 95-108.

[26] Dasgupta and Susmita, 2010. "Vulnerability of Bangladesh to cyclones in a changing climate, Potential damages and adaptation cost."

[27] Faisal, I. M. and Parveen, S., 2004. "Food security in the face of climate change, Population growth, And resource constraints, Implications for Bangladesh." Environmental Management, vol. 34, pp. 487-498.

[28] Mahmuduzzaman, M., Ahmed, Z. U., Nuruzzaman, A. K., and Ahmed, F. R., 2014. "Causes of salinity intrusion in coastal belt of Bangladesh." International Journal of Plant Research, vol. 4, pp. 8-13.

[29] Gain, A. K., Giupponi, C., and Renaud, F. G., 2012. "Climate change adaptation and vulnerability assessment of water resources systems in developing countries, A generalized framework and a feasibility study in Bangladesh." Water, vol. 4, pp. 345-366.

[30] Mondal, M. H., 2010. "Crop agriculture of Bangladesh, Challenges and opportunities." Bangladesh Journal of Agricultural Research, vol. 35, pp. 235-245.

[31] Houghton, J., 2005. "Climate change, A christian challenge and opportunity. Presentation by Sir John Houghton to the National Association of Evangelicals Washington DC."

[32] Dasgupta, S., Hossain, M. M., Huq, M., and Wheeler, D., 2015. "Climate change and soil salinity, The case of coastal Bangladesh." Ambio, vol. 44, pp. 815-826.

[33] Yu, W., Alam, M., Hassan, A., Khan, A. S., Ruane, A., Rosenzweig, C., Major, D., and Thurlow, J., 2010. Climate change risks and food security in Bangladesh. Routledge.

[34] Dastagir, M. R., 2015. "Modeling recent climate change induced extreme events in Bangladesh: A review." Weather and Climate Extremes, vol. 7, pp. 49-60.

[35] National Aeronautics and Space Administration, N., 2018. "Global climate change. Satellite sea level observations data."

[36] Wang, J. and Chameides, B., 2005. Global warming's increasingly visible impacts. Environmental Defense.

[37] Ahmed, A. U., Alam, M., and Rahman, A. A., 1999. Adaptation to climate change in Bangladesh, Future outlook. Vulnerability and adaptation to climate change for Bangladesh. Dordrecht: Springer.

[38] Ali, A., 2000. Vulnerability of Bangladesh coastal region to climate change with adaptation options. Dhaka: Bangladesh space research and remote sensing organization SPARRSO,.

[39] Cruz, J., 2007. "Ocean wave energy, Current status and future prespectives." Springer Science and Business Media,

[40] Oliver-Smith, A., 2009. "Sea level rise and the vulnerability of coastal peoples. Responding to the local challenges of global climate change in the 21st century." InterSecTions,

[41] Sarwar, G. M. and Khan, M. H., 2007. "Sea level rise, A threat to the coast of Bangladesh. Internationales Asien Forum. Arnold Bergsträsser Institut." International Quarterly for Asian Studies, vol. 38, p. 375.

[42] Khan, T. M., Singh, O. P., and Rahman, M. S., 2000. "Recent sea level and sea surface temperature trends along the Bangladesh coast in relation to the frequency of intense cyclones." Marine Geodesy, vol. 23, pp. 103-116.

[43] Singh, O. P., 2002. "Spatial variation of sea level trend along the Bangladesh coast." Marine Geodesy, vol. 25, pp. 205-212.

[44] Rahman, M. M., 2011. Country report, Bangladesh. ADBI-APO workshop on climate change and its impact on agriculture. Seoul: Republic of Korea. 
[45] Sarwar, M. G., 2013. Sea-level rise along the coast of Bangladesh. Disaster risk reduction approaches in Bangladesh. Tokyo: Springer.

[46] Islam, M. S. and Tooley, M. J., 1999. "Coastal and sea-level changes during the Holocene in Bangladesh." Quaternary International, vol. 55, pp. 61-75.

[47] Rabbani, G., Rahman, A., and Mainuddin, K., 2013. "Salinity-induced loss and damage to farming households in coastal Bangladesh." International Journal of Global Warming, vol. 5, pp. 400-415.

[48] Habibullah, M., Ahmed, A. U., and Karim, Z., 1999. Assessment of foodgrain production loss due to climate induced enhanced soil salinity. Vulnerability and adaptation to climate change for Bangladesh. Dordrecht: Springer.

[49] Mirza, M. M. and Sarkerm, M. H., 2004. Effects on water salinity in Bangladesh. The ganges water diversion, Environmental effects and implications. Dordrecht: Springer.

[50] Rahman, M. H., Lund, T., and Bryceson, I., 2011. "Salinity impacts on agro-biodiversity in three coastal, Rural villages of Bangladesh." Ocean \& Coastal Management, vol. 54, pp. 455-468.

[51] Rahman, M. M., Giedraitis, V. R., Lieberman, L. S., Akhtar, M. T., and Taminskienè, V. "Shrimp cultivation with water salinity in Bangladesh, The implications of an ecological model." Universal Journal of Public Health, vol. 1, pp. 131-142.

[52] Shamsuddoha, M. and Chowdhury, R. K., 2007. "Climate change impact and disaster vulnerabilities in the coastal areas of Bangladesh. COAST Trust, Dhaka."

[53] Ahmed, A. U., 2006. Bangladesh climate change impacts and vulnerability, A synthesis. Climate change cell. Department of Environment.

[54] Hirabayashi and Yukiko, 2013. "Global flood risk under climate change." Nature Climate Change, vol. 3, p. 816.

[55] Mirza, M. M., 2002. "Global warming and changes in the probability of occurrence of floods in Bangladesh and implications." Global Environmental Change, vol. 12, pp. 127-138.

[56] Rawlani, A. K. and Sovacool, B. K., 2011. "Building responsiveness to climate change through community based adaptation in Bangladesh." Mitigation and Adaptation Strategies for Global Change, vol. 16, pp. 845-863b.

[57] Kobayashi, K., Takara, K., Funada, M., and Takeuchi, Y., 2010. "Development of a framework for the flood economic risk assessment using vector GIS data." Journal of Disaster Research, vol. 5, pp. 657-665.

[58] Haque, C. E., 1997. Atmospheric hazards preparedness in Bangladesh, A study of warning, Adjustments and recovery from the April 1991 cyclone. Earthquake and Atmospheric Hazards. Dordrecht: Springer.

[59] Karim, M. F. and Mimura, N., 2008. "Impacts of climate change and sea-level rise on cyclonic storm surge floods in Bangladesh." Global Environmental Change, vol. 18, pp. 490-500.

[60] Thiele-Eich, I., Burkart, K., and Simmer, C., 2015. "Trends in water level and flooding in Dhaka, Bangladesh and their impact on mortality." International Journal of Environmental Research and Public Health, vol. 12, pp. 1196-1215.

[61] Loo, Y. Y., Billa, L., and Singh, A., 2015. "Effect of climate change on seasonal monsoon in Asia and its impact on the variability of monsoon rainfall in Southeast Asia." Geoscience Frontiers, vol. 6, pp. 817-823.

[62] Mohammed and Khaled, 2018. "Future floods in Bangladesh under $1.5^{\circ} \mathrm{C}, 2^{\circ} \mathrm{C}$, and $4^{\circ} \mathrm{C}$ global warming scenario." Journal of Hydrologic Engineering, vol. 23, p. 204018050.

[63] Banerjee, L., 2010. "Effects of flood on agricultural productivity in Bangladesh." Oxford Development Studies, vol. 38, pp. 339-356.

[64] Rana, M. S. and Islam, M. R., 2015. "Impact of flood hazards on the agricultural production and livelihood shifting in rural Bangladesh, A comparative study." In In5th International Conference on Water \& Flood Management ICWFM-2015. pp. 71-80.

[65] Parvin, G. A., Shimi, A. C., Shaw, R., and Biswas, C., 2016. "Flood in a changing climate, The impact on livelihood and how the rural poor cope in Bangladesh." Climate, vol. 4, p. 60.

[66] Islam, M. N., 2012. "Flood risks for the char community on the Ganges-Padma floodplain in Bangladesh." Int. J. Environ., vol. 2, pp. 106-116.

[67] Gray, C. L. and Mueller, V., 2012. "Natural disasters and population mobility in Bangladesh." Proceedings of the National Academy of Sciences,

[68] Rahman, R. and Salehin, M., 2013. Flood risks and reduction approaches in Bangladesh. Disaster risk reduction approaches in Bangladesh. Tokyo: Springer.

[69] Harun-ur-Rashid, M. and Islam, M. S., 2007. Adaptation to climate change for sustainable development of Bangladesh agriculture. Bangladesh Agriculture Research Institute.

[70] Del, N. C., 2001. "The 1998 floods in Bangladesh, Disaster impacts, Household coping strategies, And response." Intl. Food Policy Res. Inst.,

[71] Mohajan, H., 2018. "Analysis of food production and poverty reduction of Bangladesh." pp. 151-162.

[72] Chowdhury, J. U., 2000. "Bangladesh, A state at permanent flood risk. Proceedings of the international symposium on River Flood Defence, Kassel."

[73] Bangladesh Bureau of Statistics, 1997. "Yearbook of agricultural statistics of bangladesh 2016. Statistics division. Ministry of planning. Government of the people's republic of Bangladesh."

[74] Bangladesh Bureau of Statistics, B., 1997. "Yearbook of agricultural statistics of Bangladesh 2017. Statistics division. Ministry of Planning. Government of the People's Republic of Bangladesh." 
[75] Guha-Sapir, D., Hargitt, D., and Hoyois, P., 2004. Thirty years of natural disasters 1974-2003, The numbers. Presses univ. de Louvain.

[76] Paul, B. K., 2009. "Why relatively fewer people died? The case of Bangladesh's Cyclone Sidr." Natural Hazards, vol. 50, pp. 289-304.

[77] Kausher, A., Kay, R. C., Asaduzzaman, M., and Paul, S., 1996. Climate change and sea-level rise, The case of the coast. The implications of climate and sea-level change for Bangladesh. Dordrecht: Springer.

[78] Ali, A., 1996. Vulnerability of bangladesh to climate change and sea level rise through tropical cyclones and storm surges. Climate change vulnerability and adaptation in Asia and the pacific. Dordrecht: Springer.

[79] Khan, M. M., Bryceson, I., Kolivras, K. N., Faruque, F., Rahman, M. M., and Haque, U., 2015. "Natural disasters and land-use/land-cover change in the southwest coastal areas of Bangladesh." Regional Environmental Change, vol. 15, pp. 241-50.

[80] Dash, B. K., Rafiuddin, M., Khanam, F., and Islam, M. N., 2012. "Characteristics of meteorological drought in Bangladesh." Natural Hazards, vol. 64, pp. 1461-74.

[81] Eskander, S. and Barbier, E., 2016. "Adaptation to natural disasters through the agricultural land rental market, Evidence from Bangladesh." Grantham Research Institute on Climate Change and the Environment, London School of Economics,

[82] Paul, B. K., 1995. "Farmers' and public responses to the 1994-95 drought in Bangladesh, A case study."

[83] Rahman, A. A., Alam, M., Alam, S. S., Uzzaman, M. R., Rashid, M., and Rabbani, G., 2007. "Risks, Vulnerability and adaptation in Bangladesh." Human Development Report, pp. 8-8.

[84] Alam, K., 2015. "Farmers' adaptation to water scarcity in drought-prone environments, A case study of Rajshahi district, Bangladesh." Agricultural Water Management, vol. 148, pp. 196-206.

[85] Habiba, U., Shaw, R., and Takeuchi, Y., 2014. "Farmers' adaptive practices for drought risk reduction in the northwest region of Bangladesh." Natural Hazards, vol. 72, pp. 337-359.

[86] Habiba, U., Shaw, R., and Takeuchi, Y., 2011. "Drought risk reduction through a socio-economic, Institutional and physical approach in the northwestern region of Bangladesh." Environmental Hazards, vol. 10, pp. 121-138.

[87] Shahid, S. and Behrawan, H., 2008. "Drought risk assessment in the western part of Bangladesh." Natural Hazards, vol. 46, pp. 391-413.

[88] Habiba, U., Shaw, R., and Takeuchi, Y., 2012. "Farmer's perception and adaptation practices to cope with drought, Perspectives from Northwestern Bangladesh." International Journal of Disaster Risk Reduction, vol. 1, pp. 72-84.

[89] Islam and Abu, R. M. T., 2014. "Drought in Northern Bangladesh, Social, Agroecological impact and local perception." International Journal of Ecosystem, vol. 4, pp. 150-158.

[90] Mardy , T., Uddin, M. N., Sarker, M. A., Roy, D., and Dunn, E. S., 2018. "Assessing coping strategies in response to drought, A micro level study in the north-west region of Bangladesh." Climate, vol. 6, p. 23.

[91] Mazid, M. A., 2005. Rice establishment in drought-prone areas of Bangladesh. Copyright International Rice Research Institute, p. 193.

[92] Rahaman, K. M., Ahmed, F. R., and Islam, M. N., 2016. "Modeling on climate induced drought of northwestern region, Bangladesh." Modeling Earth Systems and Environment, vol. 2, p. 45.

[93] Saleh, A. F., Mazid, M. A., and Bhuiyan, S. I., 2000. Agrohydrologic and drought-risk analyses of rainfed cultivation in northwest Bangladesh. Characterizing and understanding rainfed environments. Manila, Philippines: International Rice Research Institute. pp. 233-44.

[94] Shahid, S. and Hazarika, M. K., 2010. "Groundwater drought in the northwestern districts of Bangladesh." Water Resources Management, vol. 24, pp. 1989-2006.

[95] Alamgir, M., Shahid, S., Hazarika, M. K., Nashrrullah, S., Harun, S. B., and Shamsudin, S., 2015. "Analysis of meteorological drought pattern during different climatic and cropping seasons in Bangladesh." JAWRA Journal of the American Water Resources Association, vol. 51, pp. 794-806. 